\title{
Fishing fleet typology, economic dependence, and species landing profiles of the French fleets in the Bay of Biscay, 2000-2006
}

\author{
Fabienne Daurès ${ }^{1, a}$, Marie-Joëlle Rochet ${ }^{2}$, Sylvie Van Iseghem ${ }^{1}$ and Verena M. Trenkel ${ }^{2}$ \\ 1 Ifremer, UMR AMURE, Département DEM, Technopole de Brest-Iroise, BP 70, 29280 Plouzané, France \\ ${ }^{2}$ Ifremer, Département EMH, rue de l'île d'Yeu, BP 21105, 44311 Nantes Cedex 3, France
}

Received 21 November 2008; Accepted 20 May 2009

\begin{abstract}
Thirty French fleets fishing primarily in the Bay of Biscay were defined based on techno-economic input criteria: i) 18 fishing gear or gear combinations ii) the location of fishing grounds visited during a year $(<12$ nautical miles from coast, beyond $12 \mathrm{~nm}$ or both) and iii) total vessel length ( $<20 \mathrm{~m}$ for trawlers and other gears $<24 \mathrm{~m})$. The fleets were then characterised in terms of horse power, economic dependence on a list of nine dominant commercial species (sole, Nephrops, sea bass, hake, monkfish, anchovy, cuttlefish, sardine and squid) and their contribution to the landings of these species from the Bay of Biscay. Most fleets derived the majority of their income from one or two among the nine species. Species dependencies changed little during the study period, except for those vessels targeting anchovy before the fishery restrictions starting in 2005. Fish community impacts were compared based on fleet landings' profiles. Twelve landings profiles were determined using hierarchical cluster analysis. Fleets using similar gears had the same landings' profiles and therefore exercised similar pressures on the ecosystem, though not always in the same areas. The depletion of anchovy and the closure of the fishery lead to a change in landings profile for offshore pelagic trawlers from anchovy dominance to one with a larger proportion of albacore and sea bass. During the study period, the overall vessel number decreased from 2163 to 1845 . Few vessels changed fleets, but if they did, they primarily started to fish closer to the coast, which might be a result of increasing fuel prices.
\end{abstract}

Key words: Fishing methods / Fishing vessels / Fleet dynamics / Mixed fisheries / Catch distribution / Economy / Atlantic Ocean

\begin{abstract}
Résumé - L'activité de pêche dans le golfe de Gascogne est pratiquée par 30 flottilles regroupant des navires à partir de critères technico-économiques : i) les engins ou combinaisons d'engins de pêche (on en recense 18), ii) la localisation des zones de pêche exploitées dans l'année (à moins de 12 milles nautiques de la côte, au delà de $12 \mathrm{~nm}$ de la côte) iii) la longueur totale du navire ( $<20 \mathrm{~m}$ pour les navires utilisant le chalut et $<24 \mathrm{~m}$ pour les autres navires). Les flottilles sont décrites en termes de puissance motrice, de dépendance économique à une liste de 9 espèces commerciales majeures exploitées dans le golfe de Gascogne (sole, langoustine, bar, merlu, baudroie, anchois, seiche, sardine et calmar) et de contribution aux débarquements de ces espèces. La plupart des flottilles sont majoritairement dépendantes d'une ou deux espèces parmi les 9 retenues. Les dépendances aux espèces évoluent peu au cours de la période d'étude, sauf pour les flottilles qui ciblaient l'anchois avant les mesures réglementaires de fermeture de cette pêcherie en 2005. Les pressions exercées par ces flottilles sur les communautés de poisson sont étudiées à partir de leurs profils de débarquement. Ainsi, 12 profils de débarquement sont définis à partir d'une classification hiérarchique. On observe que les flottilles utilisant des engins similaires possèdent des profils de débarquement identiques et exercent donc des pressions de même intensité sur l'écosystème, bien qu'elles ne pêchent pas systématiquement dans les mêmes zones. Les mesures réglementaires sur la pêcherie de l'anchois ont conduit à une modification des profils de débarquement des chalutiers pélagiques du large, d'un profil dominé par l'anchois, vers un profil où la proportion de thon et de bar est forte. Durant la période d'étude, le nombre total de navires a diminué passant de 2163 à 1845 . Peu de navires changent de flottilles; ceux qui l'ont fait se sont reportés vers la côte, du fait probablement de l'augmentation des prix du gasoil sur la période d'étude.
\end{abstract}

\footnotetext{
a Corresponding author: fabienne.daures@ifremer.fr
} 


\section{Introduction}

The move towards an ecosystem approach to fisheries management requires that the consequences of human activities on the marine ecosystem in all its dimensions be taken into account. To achieve this, it is now widely acknowledged that the human component in both its economic and social aspects is to be taken as part of the system (sensu FAO 2003; Garcia and Cochrane 2005) and further research on fishermen behaviour and fleet dynamics need to be undertaken (e.g. Le Floc'h et al. 2008 and 2007; Salas et al. 2004; Hilborn 1985). In particular, managing fisheries in an ecosystem perspective requires a good understanding of the mutual influences between the ecosystem and the fishing community that lives on it. This in turn relies on the definition of appropriate entities that form the basic units of these interactions and can be monitored and managed. That is, we need to define ecological units (species or groups of species or spatial areas) that will produce resources available to exploitation and bear the impact of this exploitation; and groups of vessels or gear-types that depend on these resources and exert the exploitation pressure on them. Often, in multi-species, multi-fleet fisheries, there is a wide diversity of species and fishing gears linked by a complex network of interactions; for understanding, monitoring and management purposes, some grouping is necessary (Lewy and Vinther 1992). This is not new and, in the past, groups of fishing trips targeting a given species have been sought to estimate the fishing effort on this target (e.g., Biseau 1998) or fisheries have been defined based on the spatial and temporal variability of the catch species composition (Murawski et al. 1983). What is new however with the ecosystem approach is that we need units that are relevant both to the ecological and economic dynamics as both are to be considered together as parts of the fishery system.

Analyses of the fleet-ecosystem interactions have been conducted at various scales. On the shorter time scale, catch composition at the trip or set level reveal, on the ecosystem side, spatial or seasonal variations in species assemblages available to the fleets, and on the human side, the influence of fishing tactics (e.g. small-scale spatial allocation of effort or technical settings) on catch composition, often interpreted in terms of fishing power directed at some target species (e.g., Lewy and Vinther 1992; He et al. 1997; Pech and Laloë 1997; Marchal et al. 2006; Quirijns et al. 2008). On a much longer time-scale, trends in the catch composition of vessels or fleets reflect long-term trends in species availability and the changes in fishing strategies (large-scale spatial effort allocation and species targeting) that result from these changes, but also from changes in regulations (Holley and Marchal 2004), in fleet size and composition (Bertignac 1992) and technical progress (Mahévas et al. 2004). At an intermediate scale, year-to-year variations in catch composition should reflect fluctuations and short-term trends in fish abundance and communities and in the annual amount of effort as measured by e.g. fishing days or number of vessels. The latter varies with entry and exit of vessels in the fleet, partly determined by catch fluctuations: this has been mainly examined for single fleets and one or a few species (Ward and Sutinen 1994; Pradhan and Leung 2004; Merino et al. 2007a; Merino et al. 2007b). While the annual scale is obviously relevant to assess the profitability of fishing strategies, and cost and earnings data are currently only available at this temporal scale, it has been the focus of few ecological analyses. However, if we are to tackle both economic and ecological dynamics together, this scale becomes relevant for both domains.

The Bay of Biscay is a typical multi-species multi-fleet fishery with a large diversity of species exploited by a wide range of fishing gears operated from French and Spanish ports. The French fleet operating in the Bay of Biscay consists of approximately 2000 vessels, whose size varies from 3.6 to $24 \mathrm{~m}$. They deploy gillnets, trawls, sieves, long-lines, pots and dredges; in many cases a vessel uses different types of gears during the year. The main target species are: sole, hake (both of which are currently undergoing rebuilding plans), sea bass, sardine and Nephrops. Anchovy used to be a major target species but the fishery has been mainly closed since the stock collapsed in 2005. All these stocks, excepted sea bass, are managed by TAC under the Common Fisheries Policy (CFP) of the European Union, and by gear restrictions. Since the instauration of the hake recovery plan in 2002, minimum mesh size for trawls was increased to $100 \mathrm{~mm}$ in a large part of the Bay of Biscay, but since 2006 trawlers using a square mesh panel were allowed to use a $70 \mathrm{~mm}$ mesh size (ICES 2008). A management plan for sole was adopted in February 2006, consisting of a gradual reduction of fishing mortality to increase the spawning stock. The CFP also entailed important reductions in fleet size in recent years, while the increase in fuel price created another pressure on the fleet. Detailed data on the technical characteristics of the French fleet and its landings composition are available in the Fishery Information System of Ifremer for 2000-2006.

This paper aims at matching, at the annual scale, Bay of Biscay fishery units defined by technological criteria (e.g. type of vessel and fishing gear), with their pressure on the ecosystem described by their catch composition. At the scale of the trip, Marchal (2008) categorized the French fleets fishing in the North-Atlantic based on fishing area, gear, and either meshsize or alleged target-species. He was able to forecast the catch profiles of the most species-selective fleets, like netters and pelagic trawlers. Bottom trawl catches however, seemed to be less predictable owing to changes in the demersal fish community. At the scale of the year, Duarte et al. (2009) had to use a mixture of landings' profiles clustering and segmentation by technical variables to identify manageable vessel groups. Here, we examine whether fleets defined on the basis of fine technical criteria can be grouped into a reduced set of catch profiles that can be related to similar pressure on the fish community; whether groups of catch profiles are made up of the same fleets across years; and whether vessels often change fleet.

In the following sections, first, fishing fleets, or groups of vessels having similar behaviour and fishing strategies, are defined based on input criteria (sensu Marchal 2008): type of gear used and distance from the coast, the latter considered as a proxy for vessel size. Second, economic dependence of these fleets on the major target species and their contribution to these species' production are analyzed. Third, the degree to which different fleets exert a similar pressure on the fish community, and whether this pressure is consistent over time, is examined by a multivariate analysis of their catch profiles. Finally, the 
dynamics of these fleets, in terms of the frequency of year-toyear movements of vessels between fleets, is described.

\section{Material and methods}

\subsection{Fisheries data}

Several types of fisheries data for the period 20002006 were extracted from the Fishery Information System of Ifremer (Leblond et al. 2008). The fleet data set includes technical information for each French commercial vessel registered on December 31 of each year: vessel length and age, engine power, tonnage and maritime district. The market data set (from auction halls) contains for each vessel and fishing trip the landed value and quantity by species. Direct sales are not considered in the study and may be important for some species landed by coastal small-scale vessels (e.g. glass eel). Trip data are compiled to obtain yearly sales data per vessel and per species. Negative sale values were ignored $(0.06 \%$ of entries); they correspond to a posteriori corrections by the auction hall due to customer complaints that cannot be linked with the original sales. The fishing method and activity data set was derived from an activity questionnaire filled in annually for all registered vessels (Berthou et al. 2008). The data set contains broad information on fishing location and gear used during the year, as well as landings and target species. More detailed information on the fishing gear such as mesh size was not available.

This study deals with vessels that fished primarily in the Bay of Biscay, defined as ICES areas VIII a, b and d and that were registered in one of the Atlantic maritime districts ranging from Southern Brittany to Aquitaine (Fig. 1). In order to remove vessels that primarily operated elsewhere, for example in the Celtic Sea, trawlers larger than $20 \mathrm{~m}$ and other vessels larger than $24 \mathrm{~m}$ were excluded. These vessel size limits were determined from a large scale vessel activity analysis (Leblond et al. 2007).

French vessels operating in the Bay of Biscay land over 200 species. Twenty species contributed over $80 \%$ in volume and value during the period 2000 to 2006 (Table 1). Nine species or species groups (hereafter "species") with average annual landings worth more than five millions euros were retained for detailed study: sole, Nephrops, seabass, hake, monkfish, anchovy, cuttlefish, sardine and squid (Daurès et al. 2007).

\subsection{Definition and characterisation of fishing fleets}

Homogenous fishing fleets were defined based on fishing gears used and fishing distance from the coast. There are 18 fishing gear classes, seven of which contain several gears, e.g. the class of mixed bottom and pelagic trawls (Table 2). Beam trawls are rarely used in the Bay of Biscay. The mixed gear classes correspond to vessels that change gear either within or between fishing trips. The "Inactive" class contains vessels that were registered but did not go out fishing in a given year. Three fishing distance classes have been identified. Class 1 refers to coastal vessels, fishing within $12 \mathrm{~nm}$ from the coast

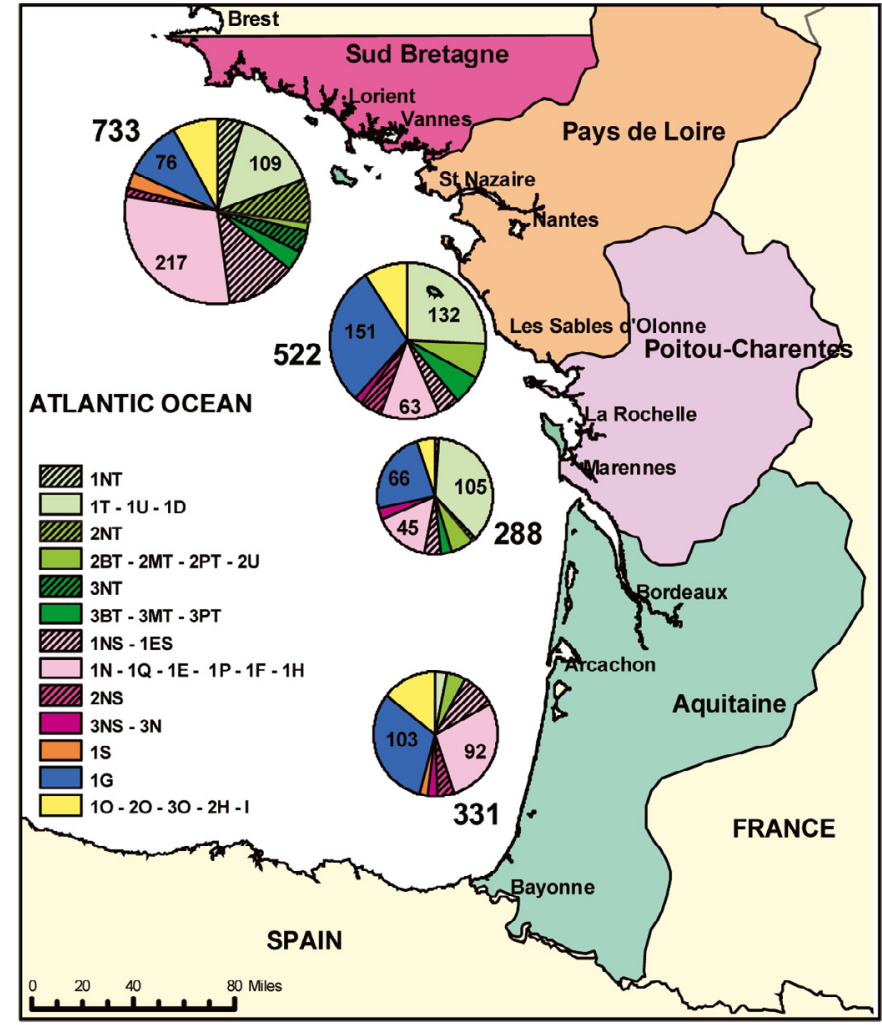

Fig. 1. Number of vessels per fleet and per maritime district (region). For gear classification into passive and active see Table 2 and for fleet definitions Table 3. Circle diameters are proportional to the number of vessels: 733 Southern Brittany, 522 Pays de Loire, 331 Aquitaine and 288 Poitou-Charentes.

during at least $75 \%$ of their fishing time. Class 3 refers to offshore vessels spending at least $75 \%$ of their fishing time between $12 \mathrm{~nm}$ to and the shelf break. Class 2 refers to shelf vessels, and it groups all other vessels, i.e. those fishing both in the coastal and offshore areas at different times of the year. A fleet is then defined by the unique combination of a fishing gear class and a distance class. Overall 31 fleets were defined in this way as not all possible combinations actually occur (Table 3).

The gear characteristics available in the fleet data set did not allow the distinction between Nephrops, pelagic and other bottom trawls or between gill nets for sole and other nets such as drift nets or gill nets targeting hake. Therefore species contribution to landings and gross revenue was used to deduce which type of gear had been used by the vessel. Thus, vessels were assigned to the Nephrops trawl fleet if Nephrops contributed at least $30 \%$ of their income a given year. For distinguishing between sole nets and other nets, all vessels that had landed any sole a given year (at least one trip targeting sole) were assigned to the fleet using sole nets. The thresholds of $30 \%$ for Nephrops income and 1 trip for sole netter were obtained by an analysis of vessel catch composition that clearly showed distinct groups with Nephrops versus fish and sole versus no sole. The assumption that catch composition is the result of specific technological choices was confirmed by gear technology experts. Data for the year 2005 was used for presenting the production capacity of each fishing fleet (number 
Table 1. List of the twenty main species landed by the French fleets in the Bay of Biscay, in decreasing order of average landings, in volume, over the period 2000-2006. The top nine species in value are marked *.

\begin{tabular}{lllrr}
\hline Code & English Name & Latin Name & Landing $(\mathrm{t})$ & Value $(\mathrm{x} \in 1000)$ \\
\hline SAR $*$ & sardine & Sardina pilchardus & 14116 & 7394 \\
ANC $*$ & anchovy & Engraulis encrasicholus & 5019 & 10549 \\
HAK $*$ & hake & Merluccius merluccius & 4674 & 19708 \\
CUT $*$ & cuttlefish & Sepia spp. & 4231 & 8591 \\
NEP $*$ & Nephrops & Nephrops norvegicus & 3866 & 32713 \\
SOL $*$ & sole & Solea solea & 3774 & 42496 \\
MON $*$ & monkfish & Lophius spp. & 3042 & 15794 \\
MAC & mackerel & Scomber scombrus & 3019 & 2543 \\
CON & conger eel & Conger conger & 2487 & 4410 \\
BAS $*$ & sea bass & Dicentrarchus labrax & 2341 & 23452 \\
HOR & horse mackerel & Trachurus trachurus & 1967 & 2052 \\
ALB & albacore & Thunnus alalunga & 1714 & 4098 \\
WHI & whiting & Merlangus merlangius & 1542 & 3417 \\
SPI & spider crab & Maja squinado & 1326 & 2717 \\
MHO & Mediterranean horse mackerel & Trachurus mediterraneus & 1194 & 2083 \\
POL & pollack & Pollachius pollachius & 1134 & 4615 \\
POU & pouting & Trisopterus luscus & 1079 & 821 \\
SQU $*$ & squid & Loligo spp. & 1000 & 5642 \\
CAT & small-spotted catshark & Scyliorhinus canicula & 964 & 525 \\
SCA & scallop & Pecten maximus & 838 & 3340 \\
\hline
\end{tabular}

Table 2. Gear classes for French vessels operating in the Bay of Biscay.

\begin{tabular}{|c|c|c|c|}
\hline Type & Code & Name & Gears \\
\hline \multirow{9}{*}{ Active } & $\mathrm{T}$ & Trawl & Bottom otter trawls, midwater pair trawls \\
\hline & BT & Bottom trawl & Bottom otter trawls, bottom pair trawls \\
\hline & PT & Pelagic trawl & Midwater pair trawls \\
\hline & MT & Bottom and pelagic trawls & $\begin{array}{l}\text { Bottom otter trawls, midwater pair trawls, midwater otter trawls, } \\
\text { bottom pair trawls }\end{array}$ \\
\hline & NT & Nephrops trawl & Bottom pair trawls, bottom otter trawls \\
\hline & $\mathrm{U}$ & Trawl \& other gears & $\begin{array}{l}\text { Bottom otter trawls, glass eel sieve, boat dredge, } \\
\text { bottom pair trawls }\end{array}$ \\
\hline & $\mathrm{S}$ & Seine & Purse seine \\
\hline & $\mathrm{D}$ & Dredge & Boat dredge \\
\hline & G & Glass eel sieve & \\
\hline \multirow{8}{*}{ Passive } & $\mathrm{N}$ & Net & Trammel nets, driftnets, set gillnets \\
\hline & NS & Sole net & Driftnets, trammel nets \\
\hline & $\mathrm{Q}$ & Nets \& pots & Pots, trammel nets, set gillnets, driftnets \\
\hline & $\mathrm{E}$ & Nets \& hooks & Set gillnets, set longlines, handlines \\
\hline & ES & Sole net \& hooks & Trammel nets, set gillnets, set longlines, handlines \\
\hline & $\mathrm{P}$ & Pots & Pots \\
\hline & $\mathrm{F}$ & Pots \& hooks & Pots, set longlines, \\
\hline & $\mathrm{H}$ & Hooks & Set longlines, handlines \\
\hline \multirow[t]{2}{*}{ Mixed } & $\mathrm{O}$ & Miscellaneous gears & \\
\hline & I & Inactive & \\
\hline
\end{tabular}

of vessels, total engine power) and the total fleet production in value and weight.

The 30 active fleets ( $i=1$ to 30 ) defined above used different gears to target the same or different species ( $j=1$ to 9$)$ in coastal or offshore areas or both. The economic dependence of fleet $i$ on species $j$ was defined as

$$
D_{i, j}=Q_{i, j} / \sum_{j} Q_{i, j}
$$

where $Q_{i, j}$ is the revenu of the vessels in fleet $i$ from selling species $j$ in a given year. The summation in the denominator is with respect to all landed species.

Conversely, the contribution of fleet $i$ to the exploitation of species $j$ is the proportion of landings of species $i$ due to fleet $j$

$$
C_{i, j}=L_{i, j} / \sum_{i} L_{i, j}
$$

where $L_{i, j}$ are the landings (weight or value) of species $j$ by fleet $i$ in a given year. The summation is with respect to all fleets $i$ that were landing species $j$. 
F. Daurès et al.: Aquat. Living Resour. 22, 535-547 (2009)

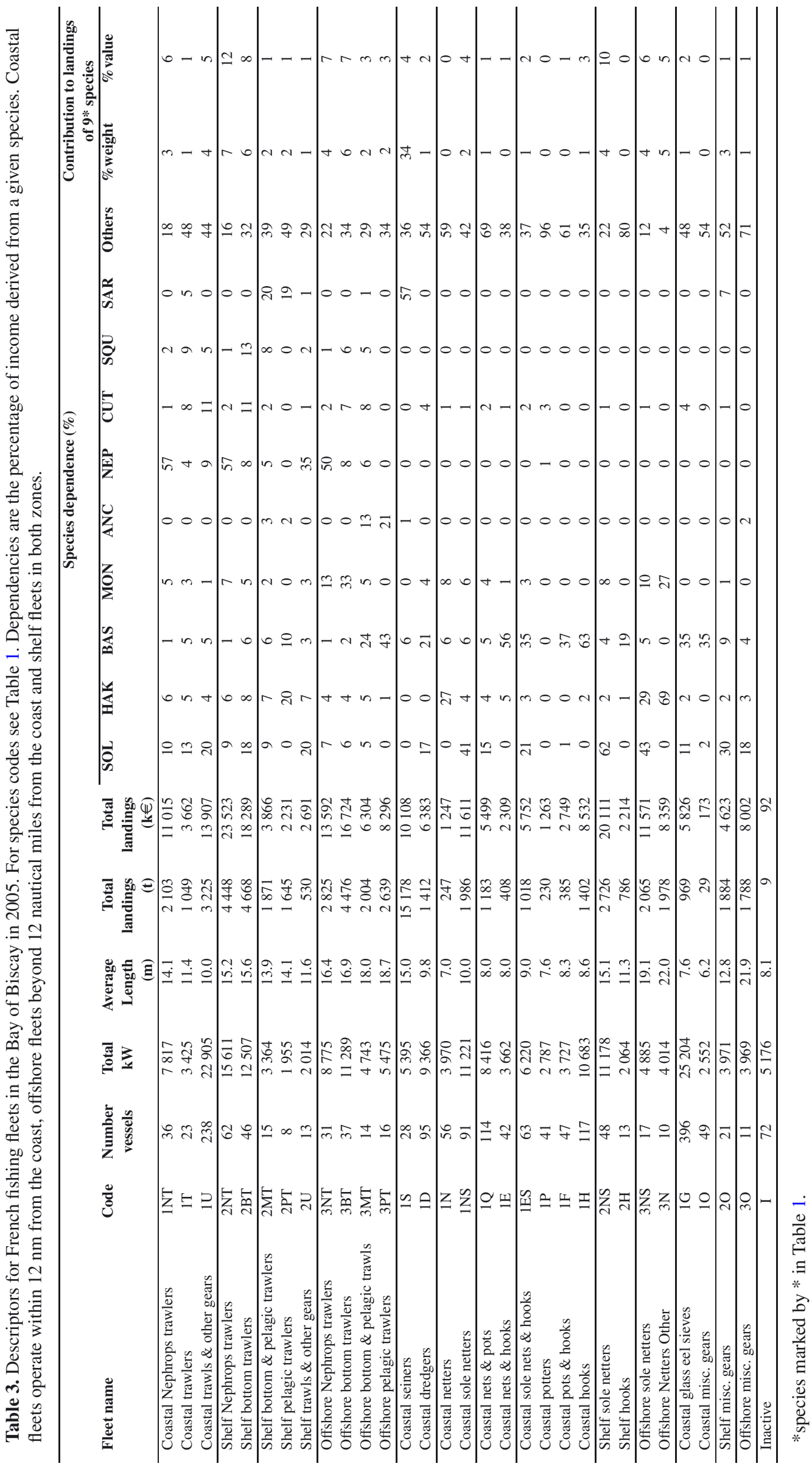


In order to identify fleets that had similar types of impacts on the ecosystem, the species composition of their annual landings (in weight) were compared. The annual landings of the major 20 species by the 30 active fleets were turned into landing profiles by dividing by total annual production by each fleet. Euclidean distance between these $30 \times 7=210$ landings' profiles was calculated and analysed by hierarchical clustering to group the most similar profiles. Initially, each profile is assigned to its own cluster and then the algorithm proceeds iteratively, at each stage joining the two most similar clusters, continuing until there is just a single cluster. The two most similar clusters are selecting according to Ward's minimum variance method that is, as those with the lowest within-cluster variance. The resulting tree was cut where the F-statistic (ratio of between- to within-cluster variance) was maximized, resulting in 12 clusters. Each cluster was characterized by its average landings' profile.

Vessel change fleets by either changing distance class, e.g. reducing the activity radius from shelf to coastal zone, or by investing in additional or new fishing gear to increase their fishing power or modify their target. Inter-annual vessel movements between fleets were characterized by transition matrices, where each cell $(i, j)$ contains the proportion of vessels of fleet $i$ that moved to fleet $j$ between years $t$ and $t+1$. When $i=j$, the vessels remained in the same fleet, that is, if all vessels would keep the same activity the diagonal of the transition matrix would consist of $1 \mathrm{~s}$ and all other cells would be $0 \mathrm{~s}$. The more there are changes between fleets, the more there will be non-empty cells outside the diagonal. As variability between annual transition matrices for the period 2000-2006 was low, only the average annual transition matrix is presented. Two additional dummy fleets were added for this study of fleet dynamics, corresponding to new vessels appearing in the Bay of Biscay, which either fished elsewhere before or were newly built vessels ("In"), and vessels leaving the Bay of Biscay, either moving elsewhere or ceasing to fish ("Out").

\section{Results}

\subsection{Description of French fleets in the Bay of Biscay}

Overall 1870 French vessels operated primarily in the Bay in 2005 , with a total engine power of $228340 \mathrm{~kW}$. They landed $67162 \mathrm{t}$ of sea products for a total value of 240.5 millions euros, for an average price of $3.7 € \mathrm{~kg}^{-1}$. Using economic input criteria regarding fishing gears and fishing distance from the coast, they were grouped into 30 active fleets plus one inactive fleet (Table 3). In 2005, 72 vessels were inactive, hence they are not expected to land anything. The number of registered vessels decreased from North to South in the Bay of Biscay (Fig. 1). The figure also shows some regional specialization. Passive gears were little used by vessels registered in Aquitaine compared to other districts. Vessels from Southern Brittany were specialised in Nephrops trawling while using relatively less glass eel sieves. Coastal seiners (1S) were absent from Pays de Loire and Poitou-Charente.

Vessel size and engine power are well connected to the fishing distance class (Fig. 2). In 2005, small vessels $(<10 \mathrm{~m}$ and $100 \mathrm{~kW}$ ) were exclusively fishing in the coastal area (fishing distance class 1), while in the offshore area (class 3) only large vessels were found (18-24 m, $>350 \mathrm{~kW})$. Intermediate vessels developed mixed localisation strategies between offshore and coastal areas. Inactive vessels were mostly small vessels $(<10 \mathrm{~m}$ and $100 \mathrm{~kW})$. It is interesting to notice that on the contrary, length and power alone may not be good predictors of the fishing distance regarding the large overlap between neighbouring categories (Fig. 2). This is a reason for the choice of distance class rather than length or power for fleet segmentation even if the latter are widely available.

Three large groups of fleets can be distinguished, based on gear type or "family" and are briefly examined below: trawler fleets, passive gear fleets and a third group of heterogeneous fleets. The average vessel age in the French Bay of Biscay fleets was 22 years in 2005. The youngest vessels were found among the group of passive gear fleets, with an average age of 11 years for shelf sole netters (2NS) and 14 years for shelf liners using hooks $(2 \mathrm{H})$.

There were 12 fleets using trawls, three of which were operating exclusively in the coastal zone (1NT, 1T and 1U), four exclusively offshore (3NT, 3BT, 3MT and 3PT) and the remaining five anywhere on the Bay of Biscay shelf (2NT, 2BT, 2MT, 2PT and 2U) (Table 3). Among trawler fleets, coastal non-exclusive trawlers (1U) were the largest fleet in terms of number of vessels (238) and total power $(23000 \mathrm{~kW})$, followed by shelf Nephrops trawlers (2NT, 62 vessels, $15000 \mathrm{~kW})$. Offshore (3BT) and shelf bottom trawlers (2BT) were important in terms of total power (more than $10000 \mathrm{~kW}$ for each fleet), but less so in terms of numbers (37 and 46 respectively). The same four trawler fleets had also the largest annual landings in weight and value. Among these, the highest value of landings was achieved by shelf Nephrops trawlers (2NT) with more than 23 millions $€$ in 2005, which was $12 \%$ of the total value landed from the Bay of Biscay. In terms of landed value per vessel, offshore Nephrops trawlers $(3 \mathrm{NT})$ were leading the trawler fleets (13.5 millions $€$ for 31 vessels). The largest vessel fishing capacity, with vessel length over $18 \mathrm{~m}$ and power over $300 \mathrm{~kW}$, was found in the offshore fleets using pelagic trawls (3MT and 3PT).

Twelve fleets used various passive gears and most of them operated in the coastal zone (Table 3). Only netters (2NS, 3NS and $3 \mathrm{~N}$ ) and vessels using hooks $(2 \mathrm{H})$ were operating outside the coastal area. The most important fleets in the passive gear group were coastal netters targeting sole (1NS), with a total of $11221 \mathrm{~kW}$ and 91 vessels and the coastal fleet using hooks (1H) with $10683 \mathrm{~kW}$ and 117 vessels. In terms of vessel numbers, coastal netters and potters (1Q) were important (114 vessels), similarly 63 vessels used both sole nets and hooks (1ES). Shelf sole netters (2NS) had a high average capacity $(234 \mathrm{~kW}$ per vessel) compared to coastal sole netters (1NS, $123 \mathrm{~kW}$ ). The former fleet also had the second highest landings in value in 2005 (20 millions $€$ ), which corresponded to $10 \%$ of the landed value in the Bay of Biscay and was comparable to the shelf Nephrops trawler fleet. Among the vessels included in this study, the offshore fleet using nets and other gears $(3 \mathrm{~N})$, consisted of the most powerful vessels (401 kW on average) with the highest average landed value in 2005 by any of the 30 active fleets, $836 \mathrm{k} €$ per vessel on average. The fleet with the 

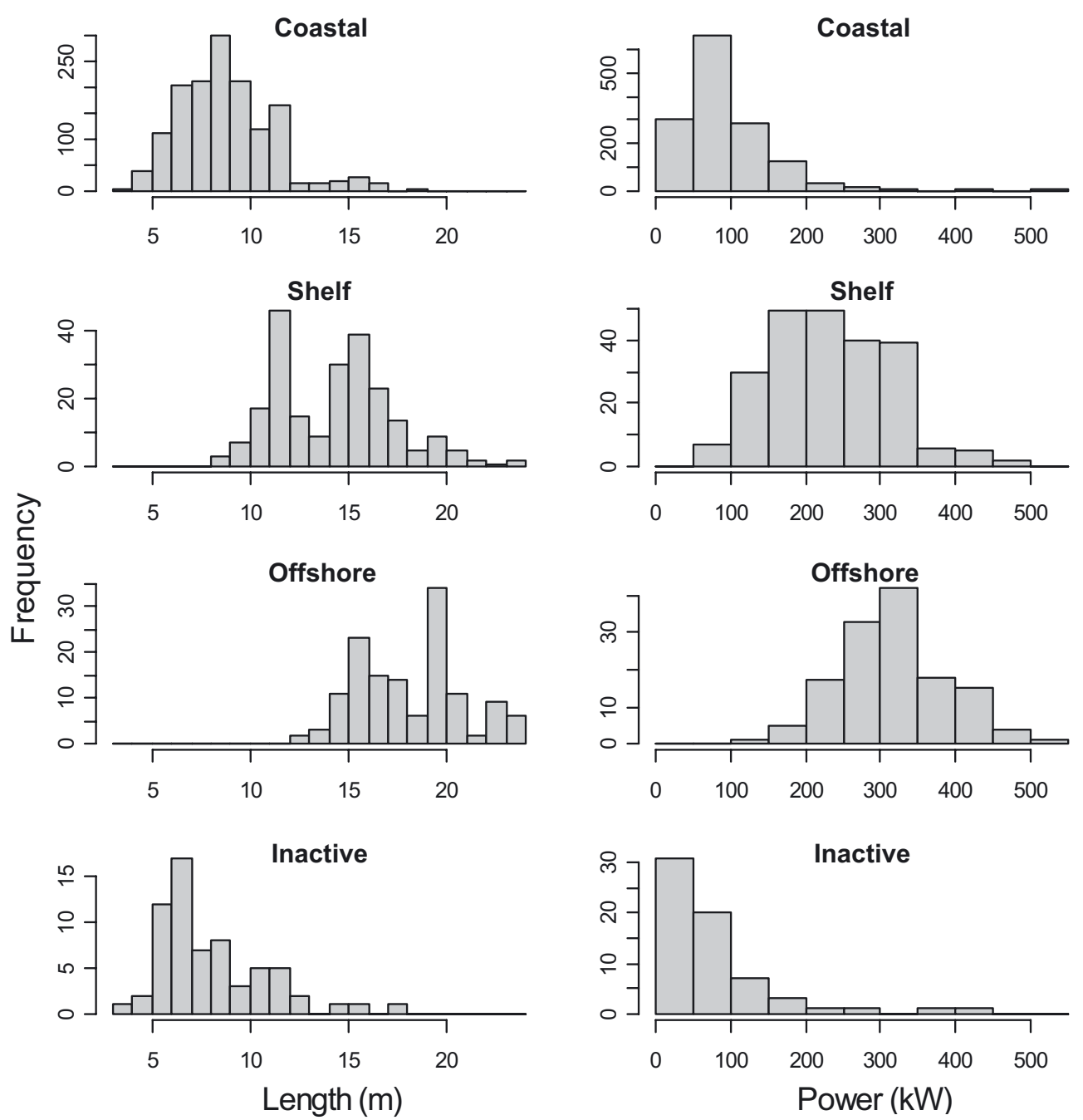

Fig. 2. Vessel size and engine power by fishing distance class in 2005; Coastal ( $<12$ nautical miles from coast), Shelf (coast to shelf break), Offshore (>12 nautical miles from coast), 4 Inactive vessels in 2005.

next highest revenue were offshore sole netters with $680 \mathrm{k} €$ on average per vessel.

The third group of fleets operated exclusively in the coastal zone and included vessels using seines, dredges and glass eel sieves $(1 \mathrm{~S}, 1 \mathrm{D}$ and $1 \mathrm{G})$. The 28 vessels of the coastal seiner fleet (1S) landed by far the largest quantity among all 30 fleets: 15000 tonnes in 2005 consisting primarily of sardine (Table 3). This fleet contributed $34 \%$ of landings (in volume), but only $4 \%$ in value, from the Bay of Biscay. The largest fleet in terms of number of vessels were the coastal glass eel sievers $(1 \mathrm{G})$, corresponding to $21 \%$ of all vessels and $11 \%$ of total capacity (in $\mathrm{kW}$ ). In contrast, the declared landings were rather low for this fleet, probably mainly due to data incompleteness.

\subsection{Economic dependence and contribution of fishing fleets}

The economic dependence of the 30 active fleets on the nine most important commercial species (in value) and their contributions to total landings were investigated to determine which fleets might be vulnerable owing to high dependence on few species, and which ones might cause important impacts on the ecosystem by large removals.

In terms of average economic species dependence during 2000-2006, among the 30 fleets, eight fleets depended for at least $50 \%$ of their revenue on a single species among the nine considered: fleets 1NT, 2NT and 3NT depended on Nephrops, $1 \mathrm{~S}$ on sardine, $1 \mathrm{E}$ and $1 \mathrm{H}$ on sea bass, $2 \mathrm{NS}$ on sole and $3 \mathrm{~N}$ on hake (Fig. 3a). Table 3 provides the values for 2005. Four fleets depended importantly (i.e. for at least $50 \%$ of revenue) on two species (for at least $20 \%$ for each species): 3 NS on sole and hake, 3PT on sea bass and anchovy, 2U on sole and Nephrops, 1ES on sole and sea bass. Several of the remaining trawler fleets depended on a wider range of species (2BT, 2MT, 3BT and 3MT). Two fleets in particular stuck out as not dependent on the nine principal species considered: fleet $1 \mathrm{P}$, which targeted mainly crustaceans, and fleet $2 \mathrm{H}$ which landed primarily conger eel, though it depended also on sea bass. The relative proportion of landings by species (in biomass) during 2000-2006 closely matched the patterns observed in economic dependence, with fleets showing high dependence in relation 
a)
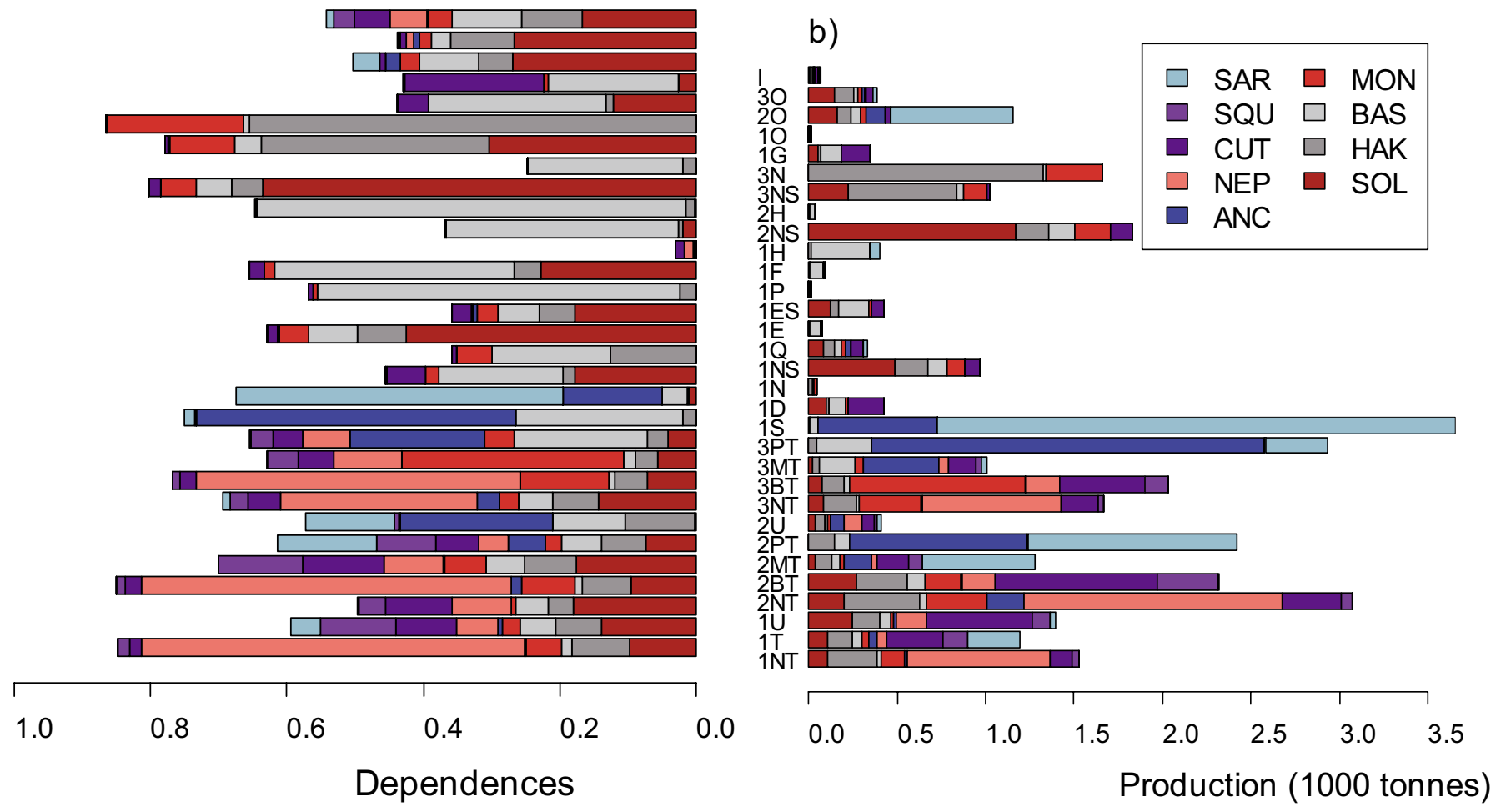

Fig. 3. a) Average dependence (proportion of landings value) and b) average production ( $\times 1000$ tonnes) of French fleets in the Bay of Biscay for nine most valuable species during 2000-2006. The bar widths are proportional to the total power of the fleets concerned, in kW. For species abbreviations, see Table 1. For fleet definitions and total power see Table 3. Total production of fleet 1S is 11493.21 tonnes.

to one species also contributing the majority of landings of that species (Fig. 3b).

Economic dependence on most species was stable for most fleets during the study period. The main exception was those exploiting anchovy (2PT, 3MT, 3PT, 3BT and 1S), the coastal fleets using trawls and other gears (1U) or glass eel sieves $(1 \mathrm{G})$ and offshore netters (3N), Fig. 4a. Owing to poor recruitment, the anchovy fishery was closed in July 2005 for a year and a very small TAC was set for 2006. As the availability of anchovy decreased from 2005 onwards, coastal seiners (1S) increased their dependence and landings of sardine, while offshore bottom and pelagic trawlers (3BT and 3PT) increased their landings and their dependence on sea bass (Fig. 4a). At the beginning of the time series, fleet $1 \mathrm{U}$ increased its economic dependence on squid and cuttlefish (Fig. 4a), increasing its landings of these species (Fig. 4b). During the same period, fleet $1 \mathrm{G}$ increased its relative dependence on sea bass despite stable landings of this species. Similarly, fleet $3 \mathrm{~N}$ obtained an increasing part of its revenue from hake (Fig. 4a), although its hake landings did not increase (Fig. 4b).

In terms of average contributions in 2005 , ten fleets contributed $80 \%$ of total landings (in weight) for the nine selected species, and three fleets contributed nearly 50\% (Table 3 ). In decreasing order of volume landed, these fleets were coastal seiners (1S, 34\%), shelf Nephrops trawlers (2NT, 7\%) and shelf bottom trawlers (2BT, $6 \%$ ). Thus, a large proportion of the biomass production from the Bay of Biscay resulted from few fleets. The concentration was slightly less marked in terms of landed value as $80 \%$ of the landing value was produced by 12 fleets and $50 \%$ by six fleets. The largest contributors were the shelf Nephrops trawlers (2NT) with a $12 \%$ share in landed value, closely followed by sole netters (2NS) with a $10 \%$ share and offshore bottom and Nephrops trawlers (3BT and 3NT) with $7 \%$ each.

\subsection{Landing profiles}

Landing profiles were created to compare the pressure exerted by the various fleets on the fish community, based on the species composition of their catches. Cluster analysis of annual landings by fleet (in weight) for the main 20 species (see Table 1) lead to the definition of 12 profiles (Fig. 5). Most profiles were dominated by one or two species, with the exception of profile 7 and 5, for which none of the 20 species was clearly determining. The nine studied species (in bold in Fig. 5) characterized most profiles, additionally conger eel was important for profiles 10 and 11 .

Fleets using similar gear had generally the same profiles thus globally a similar type of impact on the ecosystem (Table 4). For example, the landings of all Nephrops trawlers (1NT, 2NT and 3NT) were characterised by profile 1 . For all other bottom trawlers (1T, 2BT, 3BT, 1U), landings corresponded to profile 2, dominated by cuttlefish. Fleets 1D using dredges and $1 \mathrm{G}$ using glass eel sieves had the same landings profile 2 because their targets (respectively scallops and glass 

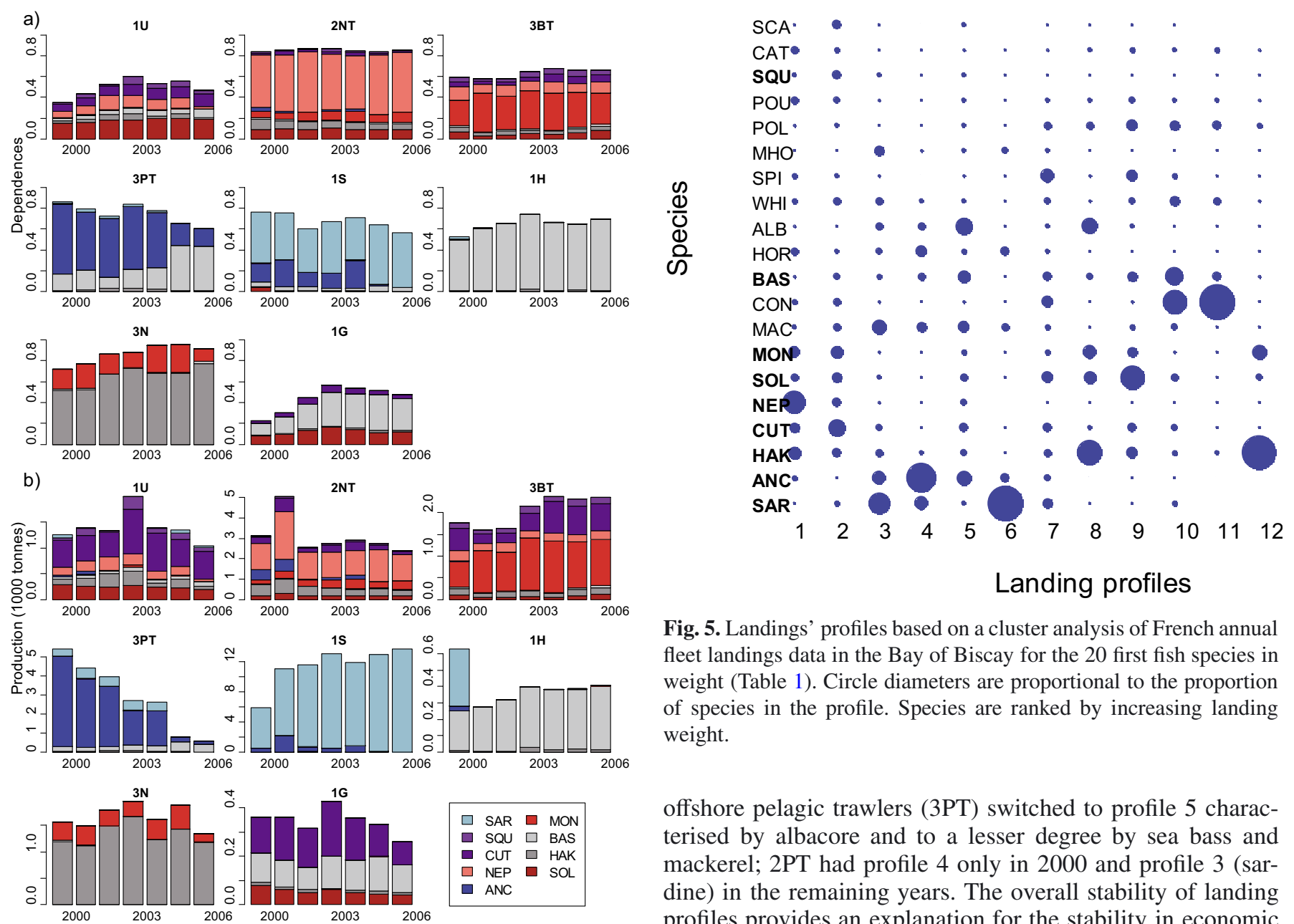

Fig. 5. Landings' profiles based on a cluster analysis of French annual fleet landings data in the Bay of Biscay for the 20 first fish species in weight (Table 1). Circle diameters are proportional to the proportion of species in the profile. Species are ranked by increasing landing weight.

offshore pelagic trawlers (3PT) switched to profile 5 characterised by albacore and to a lesser degree by sea bass and mackerel; 2PT had profile 4 only in 2000 and profile 3 (sardine) in the remaining years. The overall stability of landing profiles provides an explanation for the stability in economic dependence shown in the previous section.

Fig. 4. Time trends in a) species dependences and b) species productions for selected French fleets in the Bay of Biscay (2000-2006). For species abbreviations see Table 1. For fleet definitions, see Table 3.

eel) were not included in the 20 species analysed. Offshore pelagic trawlers (3PT) had profile 4 (anchovy) until 2004 and then shifted to the more diversified profile 5 . Two fleets had unique landings profiles: coastal seiners (1S) had profile 6 and fleet $2 \mathrm{H}$ using hooks had profile 11, resulting from their particular target species sardine and conger eel respectively. Profile 7 deserves special mention as none of the main 20 species considered in this study characterised it particularly. The reason is that the two coastal corresponding fleets (1Q and 1P), using pots mainly landed crustaceans which were not considered in this analysis which concentrates on the most valuable species in the Bay of Biscay.

For most fleets the landing profiles were rather stable during the study period with a few exceptions (Table 4). Fleet $1 \mathrm{G}$ seemed to have switched from cuttlefish (profile 2) to conger eel (profile 10) in 2006. Offshore netters (3NS and 3N) appeared to have switched between profiles 8 and 12. However, hake was the dominant species in both profiles, the main difference being the proportion of sole and albacore which was higher in profile 8 . Profile 4 , dominated by anchovy, was the only profile that disappeared during the study period, when

\subsection{Fleet dynamics}

The total number of vessels in the studied fishing fleets decreased steadily from 2163 in 2000 to 1845 in 2006, which corresponds to an average decrease of 53 vessels (or 2.6\%) per year (Fig. 6). The decreasing trend is remarkable for all fleets with the noticeable exception of the seiners which gained vessels over the period (from 23 vessels in 2000 to 28 in 2006).The largest decrease $(-22 \%)$ occurred in fleets using trawls and dredges and the smallest $(-8 \%)$ in the glass eel fleet.

The average transition matrix between the 33 fleets ( $30 \mathrm{ac}$ tive fleets, 1 inactive plus two dummy fleets for vessels entering and leaving the Bay of Biscay) revealed a rather high fidelity of vessels to their fleet (heavy right hand diagonal in Fig. 7a). This implies that few vessels changed gears or fishing grounds (distance from the coast) during the study period. When transitions between fleets were observed, they occurred mainly within the same gear class, changing the distance class. For example, on average, more vessels changed from fleet $2 \mathrm{U}$ to $1 \mathrm{U}$ than the other way round. This means that certain vessels that fished both offshore and in the coastal area stopped fishing offshore and restrained their activities to the coastal area. A similar reduction in fishing distance was observed for several other fleets. This can be seen in bubbles generally larger 
Table 4. Annual landings' profile classes for French Bay of Biscay fleets for the period 2000 to 2006. the 12 landings' profiles were determined from the hierarchical cluster analysis (cf. Fig. 4). For fleet definitions, see Table 3.

\begin{tabular}{|c|c|c|c|c|c|c|c|}
\hline $\begin{array}{l}\text { Fleet } \\
\text { code }\end{array}$ & 2000 & 2001 & 2002 & 2003 & 2004 & 2005 & 2006 \\
\hline 1NT & 1 & 1 & 1 & 1 & 1 & 1 & 1 \\
\hline 2NT & 1 & 1 & 1 & 1 & 1 & 1 & 1 \\
\hline 3NT & 1 & 1 & 1 & 1 & 1 & 1 & 1 \\
\hline 1T & 2 & 2 & 3 & 2 & 2 & 2 & 2 \\
\hline 2BT & 2 & 2 & 2 & 2 & 2 & 2 & 2 \\
\hline $\mathbf{1 U}$ & 2 & 2 & 2 & 2 & 2 & 2 & 2 \\
\hline 3BT & 2 & 2 & 2 & 2 & 2 & 2 & 2 \\
\hline$\overline{2 U}$ & 5 & 5 & 5 & 2 & 2 & 2 & 2 \\
\hline 1D & 2 & 2 & 2 & 2 & 2 & 2 & 2 \\
\hline $1 G$ & 2 & 2 & 2 & 2 & 2 & 2 & 10 \\
\hline $2 \mathrm{MT}$ & 3 & 3 & 3 & 3 & 3 & 3 & 3 \\
\hline$\overline{2 P T}$ & 4 & 3 & 3 & 3 & 3 & 3 & 3 \\
\hline 3MT & 5 & 5 & 5 & 5 & 5 & 5 & 5 \\
\hline$\overline{\text { 3PT }}$ & 4 & 4 & 4 & 4 & 4 & 5 & 5 \\
\hline$\overline{1 S}$ & 6 & 6 & 6 & 6 & 6 & 6 & 6 \\
\hline 1Q & 7 & 7 & 7 & 7 & 7 & 7 & 7 \\
\hline 1P & 7 & 7 & 7 & 7 & 7 & 7 & 7 \\
\hline $\mathbf{1 N}$ & 7 & 8 & 7 & 7 & 7 & 8 & 8 \\
\hline$\overline{3 N S}$ & 8 & 8 & 12 & 8 & 12 & 8 & 8 \\
\hline $3 \mathbf{N}$ & 8 & 8 & 12 & 12 & 12 & 12 & 12 \\
\hline 1NS & 9 & 9 & 9 & 9 & 9 & 9 & 9 \\
\hline $2 \mathrm{NS}$ & 9 & 9 & 9 & 9 & 9 & 9 & 9 \\
\hline $1 \mathrm{E}$ & 10 & 10 & 10 & 10 & 10 & 10 & 10 \\
\hline 1ES & 10 & 10 & 10 & 10 & 10 & 10 & 7 \\
\hline$\overline{1 F}$ & 10 & 10 & 10 & 10 & 10 & 10 & 10 \\
\hline $1 \mathrm{H}$ & 10 & 10 & 10 & 10 & 10 & 10 & 10 \\
\hline $2 \mathrm{H}$ & 11 & 11 & 11 & 11 & 11 & 11 & 11 \\
\hline
\end{tabular}

below than above the right hand diagonal (Fig. 7a). For example, vessels from fleet $3 \mathrm{MT}$ joined fleet 2MT, those of $3 \mathrm{NT}$ joined $2 \mathrm{NT}$ and $2 \mathrm{H}$ joined $1 \mathrm{H}$. The only major move in the opposite direction was observed for Nephrops trawlers with an average net movement from the coastal fleet $1 \mathrm{NT}$ to the shelf fleet 2NT. Vessels joining from outside the Bay of Biscay were mainly coastal ( $1 \mathrm{G}$ and $1 \mathrm{O}$ ), while vessels ceased fishing from all fleets, but mainly inactive vessels.

Inspection of annual transition matrices revealed that although some differences between years occurred, the overall pattern during the study period is described (Fig. 7a). Given the partial closure of the anchovy fishery from 2005 onwards, however, it is of interest to describe the reactions of the four fleets previously targeting anchovy in more details (Fig. 7b). Several types of reaction can be observed: change of gear, adoption of a mixture of gears, change of fishing distance, joining the fleet of inactive vessels or leaving the Bay of Biscay fishery (category "out" in Fig. 7b). Change of gear was observed for coastal seiners from fleet $1 \mathrm{~S}$ which moved to fleets $1 \mathrm{Q}$ and $1 \mathrm{H}$ and vessels from the pelagic offshore fleet which added bottom trawls and other gears to their tool box thus joining fleets 3MT and 3O. Change of fishing distance occurred for shelf pelagic trawlers (2PT) moving exclusively to the offshore area (3PT); this was observed during the whole study period and can be seen also in the average annual transition

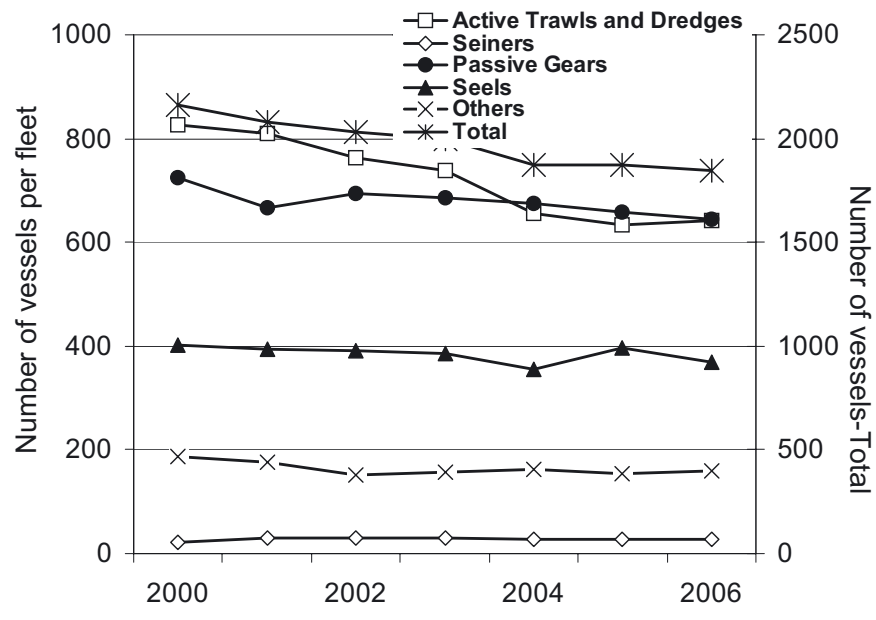

Fig. 6. Number of French vessels fishing primarily in the Bay of Biscay during 2000-2006 by broad gear category and in total.

matrix (Fig. 7a). Finally, some pelagic trawlers (2PT and 3PT) also left the Bay of Biscay fishery.

\section{Discussion}

Using fishing technology and fishing practice criteria such as fishing gear and fishing distance, both strongly linked to vessel size and engine power, 30 French fleets fishing primarily in the Bay of Biscay during the period 2000-2006 were identified. These fleets landed many species, but 20 of them contributed $80 \%$ (and 9 of them contributed $60 \%$ ) of the landings in weight and value. The fishing pressure deployed by these fleets (expressed by the landings) varied widely, with only ten fleets being responsible for about $70 \%$ of landings (in weight and value). These ten fleets represented $34 \%$ of vessels, $51 \%$ of total fishing power $(\mathrm{kW})$, indicating a strong concentration of means of production in the Bay of Biscay. Furthermore, the results revealed widely varying dependence on the nine major species, with in many cases a high degree of dependence on one or two species only. Overall, four groups of fleets can be distinguished with respect to their contribution to landings and economic dependence on the nine most important species in the Bay of Biscay:

i) Nine fleets with high contribution and dependence: Nephrops trawlers, coastal seiners and shelf and offshore sole and other netters (1NT, 2NT, 3NT, 2BT, 3BT, 1S, 2NS, $3 \mathrm{NS}, 3 \mathrm{~N})$;

ii) Two fleets with high contributions but low dependence: mixed trawlers and other gear users and sole netters in coastal areas (1U, 1NS);

iii) Seven fleets with low contributions but high dependence spanning a range of gears and all distance classes (2MT, 3MT, 2U, 3PT, 1E, 1ES, 1H);

iv) Twelve fleets with low contributions and low dependence, using mainly pots and nets or a mixture of gears primarily in the coastal zone $(1 \mathrm{~T}, 1 \mathrm{D}, 1 \mathrm{~N}, 1 \mathrm{Q}, 1 \mathrm{~F}, 1 \mathrm{P}, 2 \mathrm{H}, 1 \mathrm{G}, 1 \mathrm{O}$, 2O, 30). 
a)

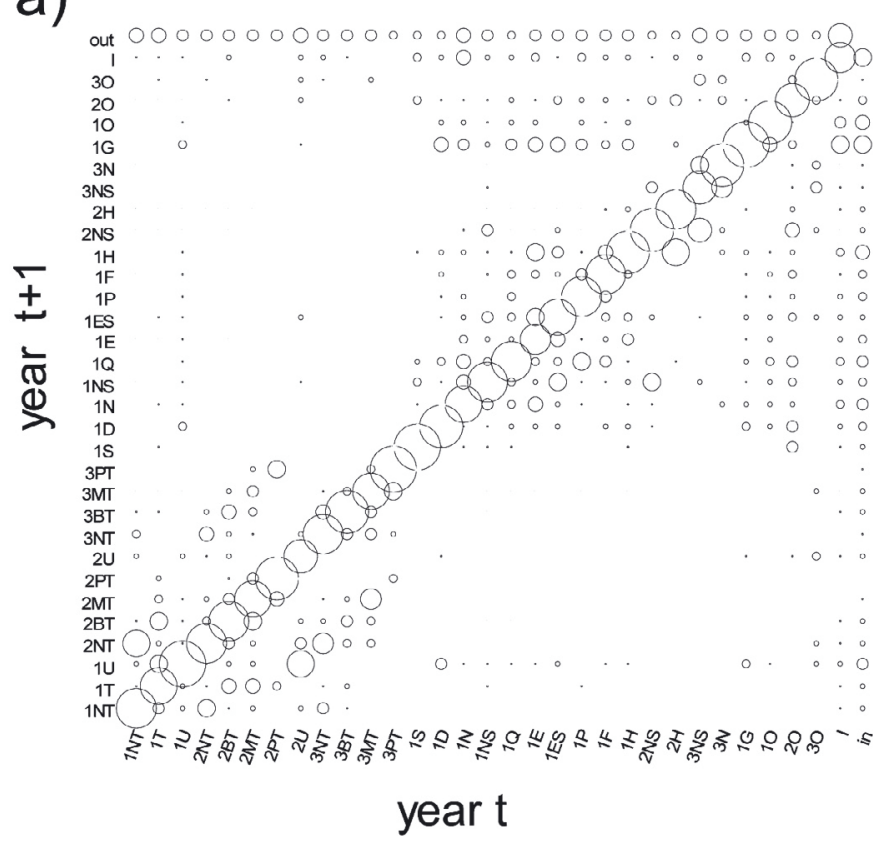

b)

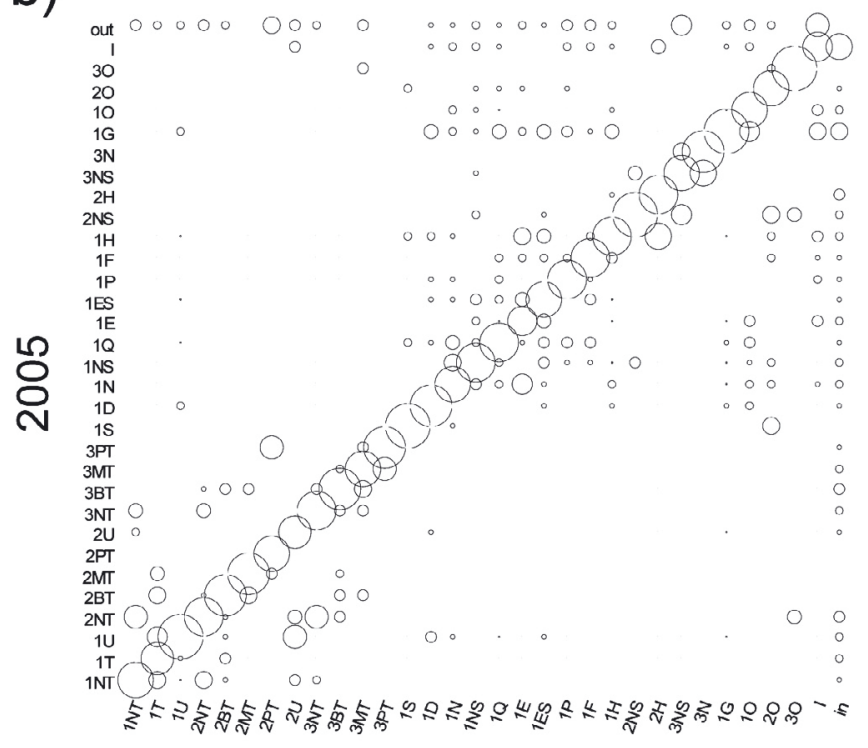

2004

Fig. 7. Transition matrix for vessel movements among fleets, a) average annual matrix 2000 to 2006, b) 2004-2005.

The analysis of landings for the period 2000-2006 yielded 12 distinct profiles and grouped fleets using similar gears to target the same species, independent of the fishing area. Thus the type of impact of a fleet on the fish community seems to be primarily determined by the gear it is using. This is not surprising considering the obvious link between the gear (and fishing practice) and the targeted species. Most of them have distinct behaviours, thus specific fishing gear is required to catch them.

The present analysis of the economic dependence of French fleets, in terms of relative value of the landings, on

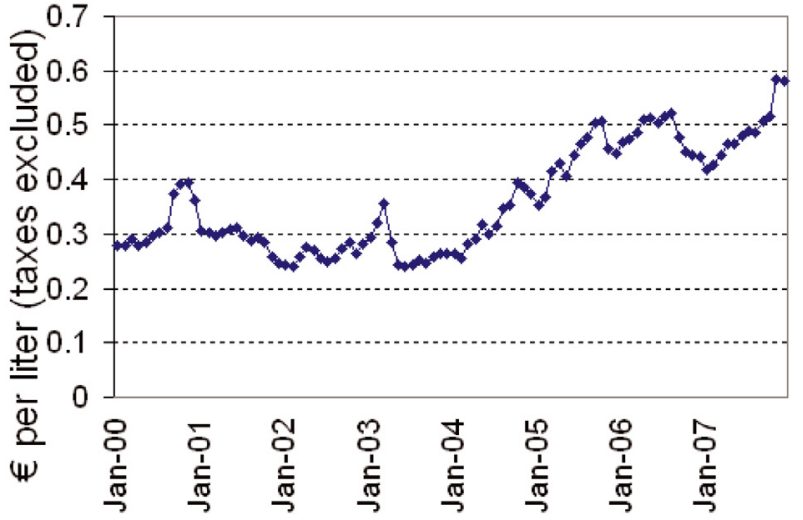

Fig. 8. Fuel prices excluding taxes (current euros) from 2000 to 2007.

different species in the Bay of Biscay, complements earlier works focussing primarily on landings in volume and technical characteristics of vessels (Dardignac 1984; Decamps et al. 1988). The historic comparison with these works shows that fishing gears have changed little over the last couple of decades, indicating that there has been no major technical innovation in the fishing sector and no new kind of pressures on the Bay of Biscay ecosystem. It is regrettable that the sparseness of detailed gear information in the system forced us to use landings compositions to indirectly derive information on gear used. The recent widening of the Data Collection Regulation (Decision 2008/949/CE) based now on the metier-fleet approach will certainly allow overcoming this lack of information as data on metier will become available under the new Data Collection Framework. Moreover, it is expected that the most detailed level of the metier will include the mesh size of the engine directed to target species. The future studies based on these datasets will show how far this issue should have impacted the main findings of this study.

Most fleets kept the same landings' composition profile during the study period. Different fleets might target the same species when available, but they may display distinct responses when: (i) target species become less available (as seen for anchovy); (ii) prices decrease; (iii) costs for fishing increase, e.g. due to increased fuel prices; (iv) or specific management measures are implemented. The response options are then not only changing target species, but also changing or adding other gear types or changing fishing distance (i.e. the operation range). The latter option may not be available to small vessels which cannot move offshore. Thus by considering fleets as groups of fishing units which have a similar type of fishing impact and behaviour (particularly in case of change) we might be better equipped to understand fleets responses to economic, environmental and governance change. However, we also show that, in a given fleet, responses may differ between vessels. Thus, future studies on vessel behaviour are required to understand the differences between vessels of the same fleet when reacting to change.

During the study period, spawning stock biomass (SSB) of Nephrops and hake showed an increasing trend while sole SSB decreased until 2003 and stabilised thereafter (ICES 2008). Sardine and sea bass were not formally assessed, but survey data indicate that sea bass population size in the Bay of 
Biscay increased (unpublished data) and sardine population size varied widely with no trend, though total landings increased (ICES 2007). The decreasing availability of sole had detectable consequences. Vessels moved from the offshore sole netter fleet to the shelf sole netters, and from those to the coastal sole netter fleet, resulting in change in economic dependences. For Nephrops, an increase in the variability of the fishing distance of Nephrops trawlers was observed with a move from both the offshore and the coastal fleet to the shelf fleet. Nonetheless, dependence on Nephrops remained stable for all three fleets. Increasing hake abundance might be responsible for the observed increasing dependence, from 50 to over $70 \%$, of the offshore netters $(3 \mathrm{~N})$ on this species. Increasing sea bass abundance and the absence of any catch or effort regulation were probably responsible for attracting vessels from outside into the coastal Bay of Biscay fleets using hooks (fleets $1 \mathrm{H}$ and $1 \mathrm{E})$. Offshore pelagic trawlers switched from anchovy to albacore and to a lesser degree to sea bass and mackerel when the anchovy fishery was closed in 2005. These results confirm the trip-level analysis of the same pelagic trawlers and some purse seiners carried out by Vermard et al. (2008), who analysed fishing trip choices during the period 2000-2005. The choice concerned the main target species of each trip, leading to the identification of four métiers defined by anchovy, see bass, albacore and a mixture of species. Using a random utility model, Vermard et al. tried to predict the consequences of the partial anchovy closure on métier choice in 2005. The model was successful in predicting the increase in the albacore and sea bass métiers but underestimated the switch to inactivity. As noted by the authors, fishing choices at the same period in the previous year were less important than expected for explaining current choices. Thus, the analysis of the annual scale for this fleet revealed a big picture complementary to the shorter time scale because the annual scale gives information on the broad spectrum of the species composition allowed by the technological choice.

Furthermore, the authors defined the fleet in terms of target species instead of fishing gear and area as done here, which resulted in vessels with the same potential species portfolio being grouped despite using different gears in different areas. It might be suspected that reactions to changes in species availability or management measures might be more similar within the fleets defined by their gear and area of operation than fleets defined by their landing profile for a given period although the response chosen is also dependent on the captain skills, risk taking position, availability of capital. Indeed, analysis of interannual transitions between fleets revealed that the reactions of the fleets targeting anchovy were quite distinct between fleets and within fleets. For example, in 2005 vessels from the shelf pelagic fleet (2PT) moved for some of them to the offshore pelagic fleet (3PT), remained in the same fleet (2PT) or for the rest of them, left the Bay of Biscay fleet ("out"). For the offshore pelagic fleet (3PT), beside remaining in the same fleet for most of the vessels and changing their species composition, some vessels moved in 2005 to the fleet of mixed bottom and pelagic trawlers (3MT).

This paper attempted to deal with one of the challenges of the ecosystem approach to fisheries (EAF) predicting change and adapting to it at low cost. It focused on the components of the fishery sector in the Bay of Biscay with the hope that they would be operational enough to meaningfully describe the interactions between the multispecies resource base and the multifleet-multigear fishery and the pressure exerted by the fleets on the fish community. The paper has shown that while keeping main patterns unchanged for years, fleets were nonetheless adapting to change through migration of some of their units between gears, species, and fishing areas. This shows that there is plasticity in the fleet composition and functioning and hence a degree of resilience. Moreover, it is shown that strong dependency on species (reflecting specialization) may not be synonymous of "vulnerability". This may add to the resilience of the resource base itself (e.g. as it adapt to climate change) and hence to the total resilience of the system. However, the observations also show that the opportunities for change (e.g. in the fishing range, fishing technology and target species) may be observed and perhaps roughly foreseen, but cannot yet be accurately predicted. More detailed studies, at vessel level, might be able to improve the understanding of change at that scale and perhaps the capacity to predict it.

Acknowledgements. We would like to thank our colleagues Patrick Berthou, Michèle Jézequel and the whole Système d'Information halieutique team for providing the data and useful discussions. We thank an anonymous referee for his comments on a previous version of the manuscript, and our editor Serge Garcia who greatly helped to improve the text and figures. This contribution received financial support from the Biodiversity project ANR-IFB 2005 "Global change, dynamics of exploited marine biodiversity, and viability of fisheries (CHALOUPE)" and the EC-funded research project FP6 - 044227 "Indicators for fisheries Management in Europe (IMAGE)".

\section{References}

Berthou P., Guyader O., Leblond E., Demanèche S., Daurès F., Merrien C., Lespagnol P., 2008, From fleet census to sampling schemes: an original collection of data on fishing activity for the assessment of the French fisheries. ICES CM 2008/ K: 12.

Bertignac M., 1992, Les rendements par espèce de la pêche chalutière hauturière française de l'Atlantique Nord-Est entre 1972 et 1989. Aquat. Living Resour. 5, 261-275.

Biseau A., 1998, Definition of a directed fishing effort in a mixedspecies trawl fishery, and its impact on stock assessments. Aquat. Living Resour. 11, 119-136.

Dardignac J., 1984, Les pêcheries du golfe de Gascogne, Bilan des connaissances. Rapp. Ifremer, DRV.

Daurès F., Planchot M., Demanèche S., Van Iseghem S., Berthou P., Leblond E., Jezequel M., 2007, Contribution et dépendance des flottilles de pêches aux espèces commerciales majeures du golfe de Gascogne. Rapp. Ifremer, DEM http://www.ifremer.fr/ docelec/doc/2007/rapport-4697.pdf.

Duarte R., Azedevo M., Afonso-Dias M., 2009, Segmentation and fishery characteristics of the mixed-species mutli-gear Portuguese fleet. ICES J. Mar.Sci. 66, 594-606.

Decamps P., Léauté J.P., 1988, Flottilles de pêches maritimes du sud du golfe de Gascogne. Ifremer, Rapp. Scient. Techn. 13.

FAO 2003, The ecosystem approach to fisheries. FAO Technical Guidelines for Responsible Fisheries, 4, Suppl. 2, FAO, Rome.

Garcia S.M., Cochrane K.L., 2005, Ecosystem approach to fisheries: a review of implementation guidelines. ICES J. Mar. Sci. 62, 311318. 
He X., Bigelow K.A., Boggs C.H., 1997, Cluster analysis of longline sets and fishing strategies within the Hawaii-based fishery. Fish. Res. 31, 147-158.

Hilborn R., 1985, Fleet dynamics and individual variation: why some people catch more fish than others. Can. J. Fish. Aquat. Sci. 32, $2-13$.

Holley J.F., Marchal P., 2004, Fishing strategy development under changing conditions: examples from the French offshore fleet fishing in the North Atlantic. ICES J. Mar. Sci. 61, 1410-1431.

Le Floc'h, P., Daurès F., Bihel J., Boncoeur J., Brigaudeau C., Thebaud O., 2007, Analyzing fishermen behaviour face to increasing energy costs - A French case study. ICES CM 2007/ M: 09.

Le Floc'h P., Daurès F., Brigaudeau C., Bihel J., 2008, A comparison of economic performance in the fisheries sector: a short and long term perspective. Mar. Policy 32, 421-431.

Leblond E., Daurès F., Berthou P., Dintheer C., 2008, The Fisheries Information System of Ifremer: a multidisciplinary monitoring network and an integrated approach for the assessment of French fisheries, including small-scale fisheries. ICES CM 2008/ K: 11.

Leblond E., Daurès F., Berthou P., 2007, La Synthèse des flottilles de pêche 2005 - Flotte mer du Nord-Manche-Atlantique. IFREMER, SIH.

Lewy P., Vinther M., 1992, Identification of Danish North Sea trawl fleets and fisheries. ICES CM 1992/ G: 45.

Mahévas S., Sandon, Y., Biseau A., 2004, Quantification of annual variations in fishing power due to vessel characteristics: an application to the bottom-trawlers of South-Brittany targeting anglerfish (Lophius budegassa and Lophius piscatorius). ICES J. Mar. Sci. 61, 71-83.

Marchal P., 2008, A comparative analysis of métiers and catch profiles for some French demersal and pelagic fleets. ICES J. Mar. Sci. 65, 674-686.

Marchal P., Andersen B., Bromley D., Iriondo A., Mahévas S., Quirijn F.J., Rackham B., Santurtún M., Tien, N., Ulrich C., 2006,
Improving the definition of fishing effort for important European fleets by accounting for the skipper effect. Can. J. Fish. Aquat. Sci. 63, 510-533.

Merino G., Maynou F., Garcia-Olívares A., 2007a, Effort dynamics in a fisheries bioeconomic model: a vessel level approach through game theory. Sci. Mar. 71, 537-550.

Merino G., Maynou, F., Garcia-Olívares A., 2007b, A new bioeconomic simulation tool for small scale fisheries based on game theory: GAMEFISTO model. Aquat. Living Resour. 20, 223-230.

Murawski S.A., Lange A.M., Sissenwine M.P., Mayo R.K., 1983, Definition and analysis of multispecies otter-trawl fisheries off the northeast coast of the United States. J. Cons. CIEM 41, 1327.

Pech N., Laloë F., 1997, Use of principal component analysis with instrumental variables (PCAIV) to analyse fisheries catch data. ICES J. Mar. Sci. 54, 32-47.

Pelletier D., Mahevas S., Drouineau H., Vermard Y., Thebaud O. Guyader O., Poussind B., 2009, Valuation of the bioeconomic sustainability of multi-species multi-fleet fisheries under a wide range of policy options using ISIS-Fish. Ecol. Model. 220, 10131333.

Pradhan N.C., Leung P., 2004, Modeling entry, stay, and exit decisions of the longline fishers in Hawaii. Mar. Policy 28, 311-324.

Quirijns F.J., Poos J.J., Rijnsdorp A.D., 2008, Standardizing commercial CPUE data in monitoring stock dynamics: accounting for targeting behaviour in mixed fisheries. Fish. Res. 89, 1-8.

Salas S., Gaertner D., 2004, The behavioural dynamics of fishers: management implications. Fish Fish. 5, 153-167.

Vermard Y., Marchal P., Mahévas S., Thebaud O., 2008, A dynamic model of the Bay of Biscay pelagic fleet simulating fishing trip choice: the response to the closure of the anchovy fishery in 2005. Can. J. Fish. Aquat. Sci. 65, 2444-2453.

Ward J.M., Sutinen J.G., 1994, Vessel entry-exit behavior in the Gulf of Mexico shrimp fishery. Am. J. Agric. Econ. 76, 916-923. 